\title{
ASSESSMENT OF KNOWLEDGE AND PRACTICE ON PREVENTION OF COMPUTER VISION SYNDROME AMONG COMPUTER PROFESSIONALS
}

*Mrs. Lakshmi G,

*Professor, Department of Medical Surgical Nursing, Amala College of Nursing, Thrissur, Kerala, India. DOI: http://doi.org/10.47211/idcij.2020.v07i03.002

Received $25^{\text {th }}$ May 2020, Accepted $5^{\text {th }}$ June 2020, Available online $10^{\text {th }}$ July 2020.

\begin{abstract}
A descriptive correlational survey was conducted among 100 computer professionals working in selected enterprises of Thiruvananthapuram city Kerala. The objectives of the study were 1) To assess the knowledge and practice regarding prevention of computer vision syndrome among computer professionals, 2) To find out correlation between knowledge and practice3) To find out association between demographic variables and knowledge regarding prevention of computer vision syndrome among computer professionals 4) To find out association between selected socio demographic variables and ergonomic practices of computer professionals. The conceptual framework for the study was based on Lafrey \& Kulboks community health promotion model which was modified as occupational health promotion model. The sampling technique is non-probability convenience sampling. A self-reporting questionnaire and an observational checklist was used for data collection. The major findings of the study were majority (81\%) of the computer professionals had inadequate knowledge and inadequate practice (79\%) regarding the prevention of computer vision syndrome. And a strong positive correlation was found between level of knowledge and practice a statistically significant association was observed between the level of knowledge and nature of work of computer professionals $(p<0.05)$ and also between gender of the computer professionals and level of practice $(p<0.05)$ an e module on healthy computing tips was provided for all professionals. The recognition of computer vision syndrome as an emerging health problem needs to be given importance and strategies need to be adopted for its prevention.
\end{abstract}

Key words: Computer vision syndrome, knowledge, practice. 


\section{INTRODUCTION}

The transformation to information era which began in the late 1870s has reached patients nadir in the current world. While only $10 \%$ were using computers for their work in 1980 s the user rate has now crossed to more than $90 \%$. Basically human eyes are adapted to stereoscopic vision i.e. the sense to perceive depth and not for near viewing and night vision, hence work in in front of a self-illuminated video display terminal at an awkward angle and unique working distance is an adaptation our visual system has to make. The American Optometric Association has defined computer vision syndrome as the complex of eye and vision problems related to prolonged exposure to computer screen the investigator felt that it is the responsibility of nurses as health care professionals to start spearheading awareness regarding this among computer professional and advocate safe practices to them

\section{THE OBJECTIVES OF THE STUDY ARE}

- To assess the knowledge regarding prevention of computer vision syndrome among computer professionals

- To assess the practice regarding prevention of computer vision syndrome among computer professionals I based on ergonomic standards'

- To find out correlation between knowledge and practice

- To find our association of demographic variables with knowledge and practice

\section{MATERIALS AND METHODS}

* Research approach -Quantitative approach

* Research design- Descriptive survey design

* Variables-knowledge and practice of computer professionals regarding prevention of computer vision syndrome

* Setting of the study-The study was conducted at selected software firms and enterprises in and around an IT campus

\section{SAMPLING CRITERIA}

Inclusion criteria

* Computer professionals who belongs to the following categories

* Computer aided designers, graphic designers, software professionals, customer service representatives

* Computer professionals with no major systemic or other associated health problems

* Computer professionals who are continuously exposed to computer monitor for at least 1 year Exclusion criteria

* Computer professionals not willing to participate

Sampling technique-non probability convenient sampling

Sample size-100

\section{TOOLS}

Tool 1 was a self-reporting questionnaire with 2 sections-

Section A Socio demographic data

Section B consisted of 25 questions regarding prevention of computer vision syndrome.

The tool was graded into three levels on the basis of the knowledge score Inadequate $(<50 \%)$, adequate $(51-75 \%)$ adequate knowledge (>75\%)

Tool 2 was a checklist with 29 items to observe the ergonomics of computer professionals and the practice was graded into three levels poor $(<50 \%)$, moderate $(51-75 \%)$ and adequate practice $(>75 \%)$ The reliability of knowledge questionnaire was established by test retest method and was found to be 0.79 and for the practice questionnaire it was done using integrate reliability and was found to be 0.81

\section{DATA COLLECTION PROCEDURE}

Formal ethical and administrative sanctions were obtained from respective departments and data was collected in 4 weeks .the sample were selected according to the inclusion criteria .Informed consent was obtained from the samples after observing the practice from the work stations knowledge questionnaire was administered to them 


\section{ARTICLES}

\section{DATA ANALYSIS}

Descriptive and inferential statistics were used for analysing data on the basis of objectives of the study

Section A Demographic profile of the computer professionals

Table .1 Frequency and percentage distribution of demographic variables of computer professionals $\mathrm{N}=\mathbf{1 0 0}$

\begin{tabular}{|l|l|l|}
\hline Demographic variables & Frequency & Percentage \\
\hline Age in years & & \\
$20-24$ & 37 & 37 \\
$25-29$ & 34 & 34 \\
$30-34$ & 20 & 20 \\
$>35$ & 9 & 9 \\
\hline Gender & & \\
Male & 80 & 80 \\
Female & 20 & 20 \\
\hline Years of experience & & \\
$1-5$ & 47 & 47 \\
$6-10$ & 33 & 33 \\
$11-15$ & 14 & 14 \\
15 and above & 6 & 6 \\
\hline Hours of daily exposure to & & \\
computer monitor & nil & \\
3-3.5hrs/day & 4 & 0 \\
3.6-4.5hrs/day & 17 & 4 \\
$4.6-6.5$ hrs/day & 79 & 79 \\
$>6.5$ hrs./ day & & 79 \\
\hline
\end{tabular}

The sample consisted of maximum number of (37\%) in the age group of 20-24 years, gender wise distribution of the samples indicate the majority were males $(80 \%)$. Majority $(47 \%)$ had $1-5$ years of experience and $>6.5$ hours of daily exposure to computer monitor

Table .2 Level of knowledge and practice regarding prevention of computer vision syndrome among computer professionals

\begin{tabular}{|l|l|l|}
\multicolumn{1}{l|}{ Lomputer professionals } & \multicolumn{2}{l|}{$=100$} \\
\hline Inadequate & Frequency & Percentage \\
\hline Moderate & 81 & $79 \%$ \\
\hline Adequate & 19 & $21 \%$ \\
\hline Level of practice & - & - \\
\hline Poor & 79 & \\
\hline Moderate & 21 & 79 \\
\hline Adequate & - & 21 \\
\hline
\end{tabular}

Majority of the subjects (81\%) had inadequate knowledge and poor practice (79\%) regarding prevention of computer vision syndrome

\section{Section C}

Table .3 Correlation between knowledge and practice of computer professionals $\mathrm{N}=100$

\begin{tabular}{|l|l|l|l|}
\hline Variable & Mean & Standard deviation & r-value \\
\hline Knowledge & 39.08 & 11.7 & 0.8 \\
\cline { 1 - 2 } Practice & 44 & 11.27 & \\
\hline
\end{tabular}

There was a strong positive correlation between knowledge and practice of computer professionals regarding prevention of computer vision syndrome 


\section{Section D}

Table 4 Association of selected socio demographic variables with knowledge regarding prevention of computer vision syndrome among computer professionals

\begin{tabular}{|c|c|c|c|}
\hline & & & $\mathrm{N}=100$ \\
\hline Variable & $<50$ & $51-75$ & $\chi 2$ \\
\hline \multicolumn{3}{|l|}{ Nature of work } & \multirow{5}{*}{$\begin{array}{l}12.42^{* *} \\
d f=3 \\
P<0.01\end{array}$} \\
\hline $\begin{array}{l}\text { Computer } \\
\text { aided design }\end{array}$ & 16 & 9 & \\
\hline $\begin{array}{l}\text { Customer } \\
\text { service } \\
\text { representative }\end{array}$ & 28 & 2 & \\
\hline $\begin{array}{l}\text { Software } \\
\text { professional }\end{array}$ & 25 & 2 & \\
\hline $\begin{array}{l}\text { Graphic } \\
\text { designer }\end{array}$ & 12 & 6 & \\
\hline
\end{tabular}

There was a statistically significant association between level of knowledge and nature of work of computer professionals $(p<0.01)$.the other variables such as age, hours of work, gender, years of experience did not show any statistically significant association

Table 6 Association of selected socio demographic variables with level of practice of computer professionals

$\mathrm{N}=100$

\begin{tabular}{|c|c|c|c|}
\hline Variable & $<50$ & $51-75$ & $\chi 2$ \\
\hline \multicolumn{4}{|l|}{ Gender } \\
\hline Male & 60 & 20 & \multirow{2}{*}{$\begin{array}{l}3.86^{*} \\
d f=1(p<0.05)\end{array}$} \\
\hline Female & 19 & 1 & \\
\hline
\end{tabular}

There was a statistically significant association between level of practice of computer professionals regarding prevention of computer vision syndrome and gender of computer professionals $(p<0.05)$ the other variables such as age, hours of work, type of work, years of experience did not show any statistically significant association

\section{DISCUSSION}

The major findings of the study were as follows

> Majority (81\%) of the computer professionals had inadequate knowledge regarding prevention of computer vision syndrome. The mean overall knowledge of the computer professionals was 39.07(SD11.7)

$>$ The assessment of the ergonomic work practices of computer professionals revealed that majority $(79 \%)$ of them have poor work practices

$>\quad$ The mean score for practice was 44 (SD11.3)

$>$ The correlation between knowledge and practice showed that there was a highly positive correlation between knowledge and practice of computer professionals regarding prevention of computer vision syndrome hence the null hypothesis $\mathrm{H} 01$ was rejected

$>$ On associating the socio demographic variables with the level of knowledge it was found that there was a statistically significant association between level of knowledge and nature of work of computer professionals $(p<0.01)$. It might be because of the difference in nature of exposure to knowledge and basic job training which varies in different occupations

$>$ There was a statistically significant association between gender and level of practice of computer professional $(p<0.05)$ this was supported by other studies which reported higher prevalence of work related strain injury in women which might be because of the physical psychosocial and physical strain the women undergo at home and workplace 


\section{ARTICLES}

The present study assesses the knowledge and practice of computer professional regarding prevention of computer vision syndrome. The results revealed that majority of the professionals had inadequate knowledge and practice regarding prevention of computer vision syndrome. This finding indicates the need for a preventive education Programme to be given to all computer professionals. Hence the investigator prepared a an e -module on healthy computing tips and distributed it among the samples via email

\section{REFERENCES}

1. Anshel jeffery "visual ergonmics in work place" $3^{\text {rd }}$ edtion, London, aylor anf francis Its , 2018

2. Sen A., Richardson S. A study of computer-related upper limb discomfort and computer vision syndrome. Journal of Human Ergology. 2007;36(2):45-5

3. Klamm J, Tarnow KG. Computer vision syndrome: a review of literature. Medsurg Nurs. 2015;24(2):89-93

4. Akinbinu TR, Mashalla YJ. Knowledge of computer vision syndrome among computer users in the workplace in Abuja, Nigeria. Journal of Physiology and Pathophysiology. 2013;4:58-63

5. Shrivastava SR, Bobhate PS. Computer related health problems among software professionals in Mumbai: A cross-sectional study. International Journal of Health and Allied Sciences. 2012; 1:74.

6. Reddy SC, Low CK, Lim YP, Low LL, Mardina F, Nursaleha MP. Computer vision syndrome: a study of knowledge and practices in university students. Nepalese Journal of Ophthalmology. 2013;5:161-8 